\title{
Comparative Effects of New Generation Oxazaphosphorines on the Size and Viability of Human Acute Myeloblastic Leukemia Cells*
}

\author{
Lidia MAZUR, Małgorzata OPYdo-ChANeK, Katarzyna WoJCIESZEK, Marta STOJAK, \\ and Ulf NIEMEYER
}

Accepted October 5, 2011

\begin{abstract}
Mazur L., Opydo-Chanek M., Wojcieszek K., Stojak M., Niemeyer U. 2012. Comparative effects of new generation oxazaphosphorines on the size and viability of human acute myeloblastic leukemia cells. Folia biologica (Kraków) 60: 35-40.

Mafosfamide cyclohexylamine salt (D-17272), 4-hydro-peroxy-cyclophosphamide (D-18864), and $\beta$-D-glucose-isophosphoramide mustard (D-19575, glufosfamide) are three new generation oxazaphosphorine agents. The aim of the present study was to compare the cell response to the action of these three oxazaphosphorines. The experiments were performed in vitro on human acute myeloblastic leukemia ML-1 cells. After exposure of ML-1 cells to the oxazaphosphorines, the size, viability and count of these cells were determined. The research was conducted using the spectrophotometric MTT assay and the electronic Beckman Coulter method. The temporary changes in the ML-1 cell size, viability and count, were dependent on the oxazaphosphorine agent tested, its dose, and the time intervals after its application. Among the three oxazaphosphorine agents, D-18864 proved to be the most cytotoxic, and D-19575 was characterized by the lowest cytotoxicity. The results suggest the possibility of using the electronic sizing and counting method and the MTT assay as a rapid in vitro test for assessing leukemic cell sensitivity to the action of new potential chemotherapeutic agents.
\end{abstract}

Key words: Human leukemic ML-1 cells, oxazaphosphorines, cytotoxicity, cell size, viability, and count.

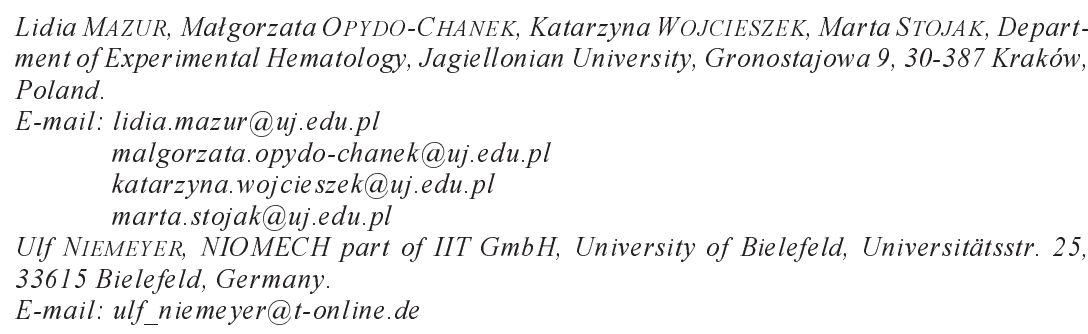

Oxazaphosphorines are a class of alkylating agents, widely used in chemotherapy. However, to improve the therapeutic index of this class of chemotherapeutic agents, new generation oxazaphosphorines have been developed. Mafosfamide cyclohexylamine salt (D-17272), 4-hydro-peroxy-cyclophosphamide (D-18864), and $\beta$-D-glucose-isophosphoramide mustard (D-19575, glufosfamide) are new oxazaphosphorine derivatives. The cell response to the action of these alkylating compounds is still under experimental and clinical investigation (BODY and YULE 2000; ENGEL et al. 2000; SEKER et al. 2000; BLANEY et al. 2005; ZHANG et al. 2005a, 2005b;
LIANG et al. 2007; GIRAUD et al. 2010; MAZUR et al. 2011).

The influence of the new generation oxazaphosphorines on pathological hematopoietic cells is not completely known yet. Available information on the cytotoxic activity of D-17272, D-18864, and D-19575 in human leukemic cells is still scarce (STYCZYŃSKI et al. 2000a, 2000b; GOLDSTEIN et al. 2008; MAZUR et al. 2009, 2010; OPYDO-CHANEK et al. 2010a, 2010b).

Therefore, the objective of the present study was to evaluate in vitro cytotoxicity of three new oxazaphosphorine agents on human acute myelo- 
blastic leukemia ML-1 cells. Temporary changes in the size, viability and count of ML-1 cells subjected to the exposure of D-17272, D-18864, and D-19575, were analyzed using the electronic Beckman Coulter method and the MTT assay.

\section{Material and Methods}

\section{Cells}

Human acute myeloblastic leukemia ML-1 cells (European Collection of Cell Culture, ECACC, Sigma Aldrich, Catalogue No. 88113007) were maintained in RPMI 1640 (Gibco BRL Life Technologies) supplemented with $10 \%$ fetal calf serum (GIBCO BRL Life Technologies), 2 mM L-glutamine (Sigma Aldrich), and antibiotic antimycotic solution (AAS, Sigma Aldrich). AAS contained 20 units of penicillin, $20 \mu \mathrm{g}$ streptomycin and $0.05 \mu \mathrm{g}$ amphotericin B. Leukemic ML-1 cells were passaged every third day. The cells grew expotentially at $37^{\circ} \mathrm{C}$ in an atmosphere of 5\% $\mathrm{CO}_{2}$ in air (HERAcell incubator, KendroLab). The cultures were periodically tested for Mycoplasma infection.

\section{Chemicals}

Mafosfamide cyclohexylamine salt (D-17272, CAS No. 84210-80-0), 4-hydro-peroxy-cyclophosphamide (D-18864, CAS No. 39800-16-3) and glufosfamide (D-19575, $\beta$-D-glucose-isophosphoramide mustard, CAS No. 132682-98-5) were obtained from NIOMECH (Bielefeld, Germany). D-17272, D-18864 and D-19575 were dissolved in aqua pro injectione (Polpharma). All solutions were freshly prepared directly before treatment of ML-1 cells.

\section{Agent doses and cell treatment}

After a dilution of the cell suspension to a density of $15 \times 10^{4}$ cells $/ \mathrm{ml}$ medium, ML-1 cells were exposed for $30 \mathrm{~min}$ to the oxazaphosphorine agent. D-18864 was applied at a dose of $10 \mu \mathrm{g} / \mathrm{ml} \mathrm{me-}$ dium, D-19575 at a dose of $100 \mu \mathrm{g} / \mathrm{ml}$ medium, and D-17272 was given at doses of $10 \mu \mathrm{g} / \mathrm{ml}$ and $100 \mu \mathrm{g} / \mathrm{ml}$ medium. The control material consisted of untreated ML-1 cells. After 30 min treatment with the oxazaphosphorine agent, leukemic ML-1 cells were centrifuged for $10 \mathrm{~min}$ at $1000 \mathrm{rpm}$ and the supernatant was discarded. Then the cells were washed in $2 \mathrm{ml}$ of PBS (BioMed) and pelletted by centrifugation for $7 \mathrm{~min}$. The wash and centrifugation were repeated once more and the cells resuspended in the complete RPMI 1640 medium.

\section{ML-1 cell analysis}

Temporary alterations occurring in human leukemic ML-1 cells were assessed at 24h, 48h, and $72 \mathrm{~h}$ after the cell exposure to the oxazaphosphorine agent. At these three time intervals, the size, viability and count of ML-1 cells, were determined.

Beckman Coulter method of cell sizing and counting

The electronic Beckman Coulter method was applied to determine ML-1 cell size and count. The Beckman Coulter method of cell sizing and counting is based on the detection and measurement of changes in electrical resistance produced by a cell suspended in a conductive liquid traversing through a small aperture. The passage of each individual cell momentarily modulates the impedance of the electrical path between two electrodes located on each side of the aperture. An electrical pulse, suitable for sizing and counting, results from the passage of each cell through the aperture. While the amplitude of the produced electrical pulse depends on the cell volume, the number of pulses indicates the cell count.

Samples of ML-1 cell suspension were taken from flasks and immediately diluted in ISOTON II (Beckman Coulter filtered electrolyte solution based on $0.9 \%$ saline). $500 \mu \mathrm{l}$ of the cell suspension was added to $4.5 \mathrm{ml}$ of ISOTON II. After the dilution of ML-1 cell suspension, individual leukemic cells were measured using the Z2 Coulter counter (Beckman Coulter, USA). The count and volume distributions of ML-1 cells were obtained using the counter equipped with a $100 \mu \mathrm{m}$ diameter orifice. The flow rate was $500 \mu \mathrm{l} / 12.5 \mathrm{sec}$. The range for cell measurement was determined as 162-10 $370 \mathrm{fL}$. The cell volume and count was analyzed at 851-10 $370 \mathrm{fL}$. The instrument was calibrated using $10 \mu \mathrm{m}$ diameter latex beads (Beckman Coulter CC size standard). The mean cell volume, modal peak and the cell count, were determined using Z2 AccuComp software (Beckman Coulter, USA).

\section{MTT viability assay}

The in vitro MTT test was designed for spectrophotometrically determining the viability of cell populations. MTT (3-[4,5-dimethylthiazol-2-yl] -2,5-diphenyl tetrazolium bromide) is the key component used in the MTT assay. In viable, metabolically active cells, the tetrazolium ring is cleaved, yielding formazan crystals. Changes in the metabolic activity of cell populations result in a concomitant change in the amount of formazan formed. 
MTT (Sigma-Aldrich) was dissolved in RPMI 1640 medium, at a concentration of $5 \mathrm{mg} / \mathrm{ml}$, and filtered through a $0.2 \mu \mathrm{m}$ filter. $100 \mu \mathrm{l}$ of the yellow MTT solution was added to each well of a 24well plate containing $1 \mathrm{ml}$ of the cell suspension. The cells were then incubated at $37^{\circ} \mathrm{C}$ with $5 \%$ $\mathrm{CO}_{2}$. A blank solution was prepared according to the above procedure using complete medium without cells. After the three-hour incubation period, the resulting formazan crystals were dissolved with $1 \mathrm{ml}$ of acidified isopropanol $(0.05 \mathrm{~N} \mathrm{HCl}$ in absolute isopropanol), and absorbance of the obtained solution was measured at a wavelength of $570 \mathrm{~nm}$ using a Pharmacia Ultrospec III spectrophotometer (Pharmacia). The extent of MTT conversion in cells was also expressed as a percentage value of the control.

\section{Statistical evaluation}

Statistical significance of differences in the mean cell volume and the mean amount of formazan formed as well as in the mean cell count, were evaluated by an analysis of variance and the Duncan's new multiple range test.

\section{Results}

\section{Effects of oxazaphosphorines on ML-1 cells}

The influence of three new generation oxazaphosphorines on human acute myeloblastic leukemia ML-1 cells, was determined. The effects of D-18864, D-17272, and D-19575, on the leukemic cell size (Table 1 and Table 2, Fig. 1), and their viability (Table 3, Fig. 2) and count (Table 4), observed at $24 \mathrm{~h}, 48 \mathrm{~h}$, and $72 \mathrm{~h}$ after the oxazaphosphorine agent application, were compared.

\section{Mean volume of ML-1 cells (Table 1, Fig. 1)}

In comparison with the controls, the mean volume of ML-1 cells was increased in all the experimental groups and at all three time intervals $24 \mathrm{~h}$, $48 \mathrm{~h}$, and $72 \mathrm{~h}$ after the leukemic cell exposure to the action of the oxazaphosphorine agents. Among ML-1 cells treated with the oxazaphosphorine agents, the greatest mean volume was obtained when D-17272 was given at a higher dose of 100 $\mu \mathrm{g} / \mathrm{ml}$ medium, and the smallest mean volume of the leukemic cells was observed after D-19575 application, at the same dose. The increased mean volume of ML-1 cells exposed to D-17272 at two doses, $10 \mu \mathrm{g} / \mathrm{ml}$ and $100 \mu \mathrm{g} / \mathrm{ml}$ medium, appeared to be dose-dependent. The mean volume was found to be smaller in ML-1 cells treated with D-17272, at a dose of $10 \mu \mathrm{g} / \mathrm{ml}$ medium, than in those exposed to D-18864 at the same dose.

Modal peak of the volume distribution curve (Table 2, Fig. 1)

In relation to the controls, greater values in the modal peaks of the volume distribution curves were found in ML-1 cells exposed to the action of the oxazaphosphorines, except for the value obtained

Table 1

The mean volume of ML-1 cells after their exposure to the oxazaphosphorine agents

\begin{tabular}{|c|c|c|c|c|c|}
\hline \multirow{2}{*}{\multicolumn{3}{|c|}{ Group characteristic }} & \multicolumn{3}{|c|}{ Mean cell volume (fL) } \\
\hline & & & \multirow{2}{*}{$\begin{array}{c}24 \mathrm{~h} \\
\text { mean } \pm \mathrm{SD} \\
\end{array}$} & \multirow{2}{*}{$\begin{array}{c}48 \mathrm{~h} \\
\text { mean } \pm \mathrm{SD} \\
\end{array}$} & \multirow{2}{*}{$\begin{array}{c}72 \mathrm{~h} \\
\text { mean } \pm \mathrm{SD} \\
\end{array}$} \\
\hline No. & agent given & agent dose & & & \\
\hline I & D-18864 & $10 \mu \mathrm{g} / \mathrm{ml}$ & $\begin{array}{c}2,3,4,5,48 \mathrm{~h}, 72 \mathrm{~h} \\
3729 \pm 75\end{array}$ & $\begin{array}{c}2,3,4,5,24 \mathrm{~h}, 72 \mathrm{~h} \\
5114 \pm 74\end{array}$ & $\begin{array}{c}2,3,4,5,24 \mathrm{~h}, 48 \mathrm{~h} \\
3926 \pm 89 \\
\end{array}$ \\
\hline II & D-17272 & $10 \mu \mathrm{g} / \mathrm{ml}$ & $\begin{array}{c}1,3,4,5,48 \mathrm{~h}, 72 \mathrm{~h} \\
3385 \pm 51\end{array}$ & $\begin{array}{c}1,3,4,5,24 \mathrm{~h}, 72 \mathrm{~h} \\
2961 \pm 85\end{array}$ & $\begin{array}{c}1,3,4,5,24 \mathrm{~h}, 48 \mathrm{~h} \\
2440 \pm 49\end{array}$ \\
\hline III & D-17272 & $100 \mu \mathrm{g} / \mathrm{ml}$ & $\begin{array}{c}1,2,4,5,48 \mathrm{~h}, 72 \mathrm{~h} \\
3902 \pm 62\end{array}$ & $\begin{array}{c}1,2,4,5,24 \mathrm{~h}, 72 \mathrm{~h} \\
6033 \pm 87\end{array}$ & $\begin{array}{c}1,2,4,5,24 \mathrm{~h}, 48 \mathrm{~h} \\
5238 \pm 67 \\
\end{array}$ \\
\hline IV & D-19575 & $100 \mu \mathrm{g} / \mathrm{ml}$ & $\begin{array}{c}1,2,3,5,48 \mathrm{~h}, 72 \mathrm{~h} \\
2629 \pm 53\end{array}$ & $\begin{array}{c}1,2,3,5,24 \mathrm{~h}, 72 \mathrm{~h} \\
2819 \pm 72\end{array}$ & $\begin{array}{c}1,2,3,5,24 \mathrm{~h}, 48 \mathrm{~h} \\
2322 \pm 90 \\
\end{array}$ \\
\hline V & \multicolumn{2}{|c|}{ control } & $\begin{array}{l}1,2,3,4,72 \mathrm{~h} \\
2290 \pm 37\end{array}$ & $\begin{array}{l}1,2,3,4,72 \mathrm{~h} \\
2309 \pm 96\end{array}$ & $\begin{array}{c}1,2,3,4,24 h, 48 h \\
2199 \pm 91\end{array}$ \\
\hline
\end{tabular}

The data are presented as mean values \pm standard deviation.

Statistically significant differences at $\mathrm{P}<0.05$

Differences between groups: different from Group I - 1, Group II -2, Group III - 3, Group IV - 4, Group V - 5 .

Differences within each group: different from $24 \mathrm{~h}-24 \mathrm{~h}, 48 \mathrm{~h}-48 \mathrm{~h}, 72 \mathrm{~h}-72 \mathrm{~h}$. 

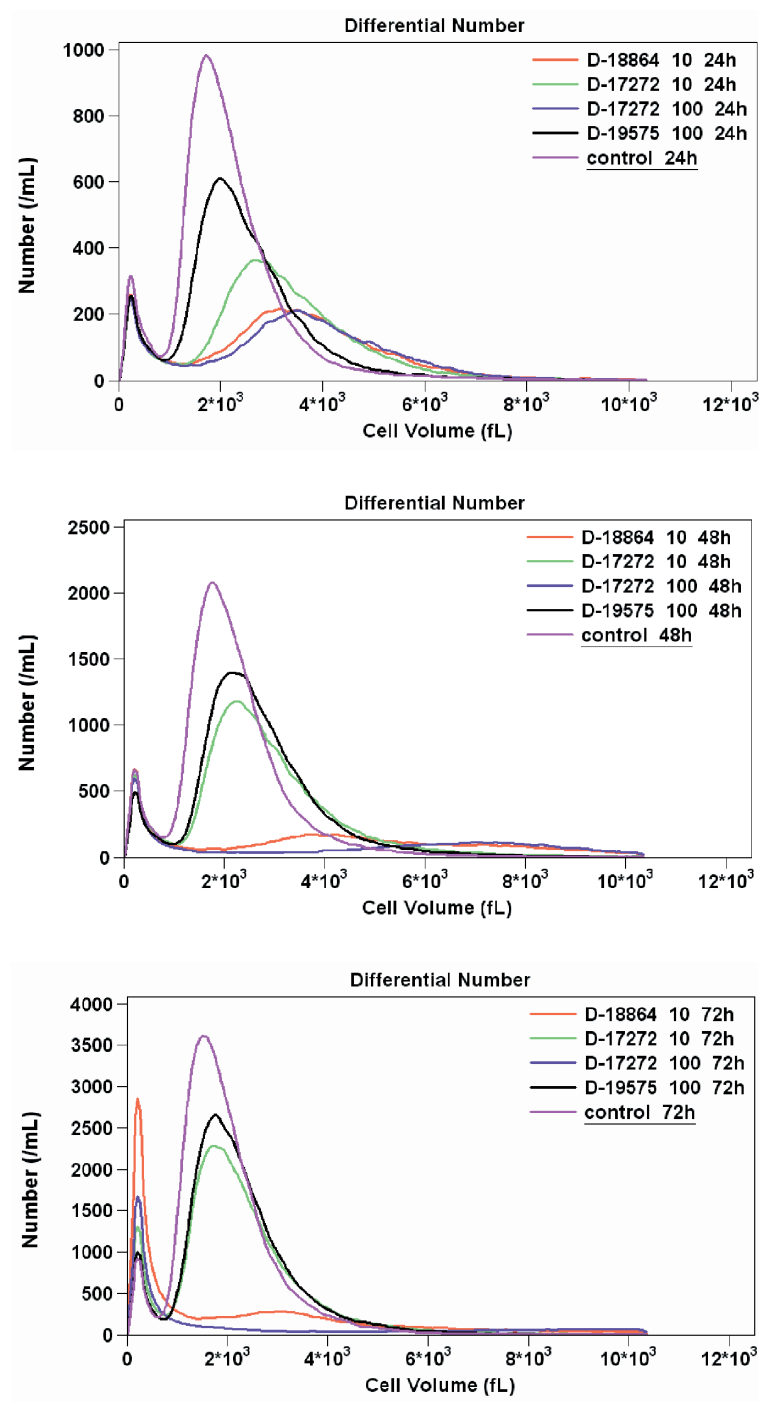

Fig. 1. The volume of ML-1 cells exposed to the oxazaphosphorines The volume distribution curves of ML-1 cells analyzed with the Beckman Coulter counter. The peaks on the left represent cellular debris, presumably apoptotic bodies and necrotic cell fragments, which were excluded from the analysis of the ML-1 cell volume. at $72 \mathrm{~h}$ after D-17272 application at a higher dose of $100 \mu \mathrm{g} / \mathrm{ml}$ medium. The patterns of temporary changes in the modal peak of the volume distribution curve are correlated with those of the mean volume of ML-1 cells.

\section{ML-1 cell viability (Table 3, Fig. 2)}

The cell viability is correlated with the optical density of formazan solution. Compared with the controls, the optical density of formazan solution decreased $24 \mathrm{~h}, 48 \mathrm{~h}$, and $72 \mathrm{~h}$ after the treatment of ML- 1 cells with D-18864, D-17272, and at 24h and $72 \mathrm{~h}$ after their exposure to the action of D-19575. Among ML-1 cells treated with the oxazaphosphorine agents, the values of the optical density of formazan solution were found to be greater following D-19575 application at a dose of $100 \mu \mathrm{g} / \mathrm{ml}$, and when D-17272 was given at a dose of $10 \mu \mathrm{g} / \mathrm{ml}$ medium, and smaller values were obtained when D-18864 was applied at a dose of 10 $\mu \mathrm{g} / \mathrm{ml}$ and D-17272 at a dose of $100 \mathrm{~g} / \mathrm{ml}$ medium.

The viability rate indicating the extent of MTT conversion to formazan, and expressed as the percentage values of the controls, appeared to be distinctly reduced in ML-1 cells exposed to D-18864 at a dose of $10 \mu \mathrm{g} / \mathrm{ml}$ and especially in those treated with D-17272 at a dose of $100 \mu \mathrm{g} / \mathrm{ml}$ medium.

\section{ML-1 cell count (Table 4)}

In comparison with the controls, the cell count of ML-1 cells decreased in all experimental groups and in all three time intervals at $24 \mathrm{~h}, 48 \mathrm{~h}$, and $72 \mathrm{~h}$ after the leukemic cell exposure to the action of the oxazaphosphorine agents. Among ML-1 cells treated with the oxazaphosphorine agents, the smallest cell number was found when D-17272 was given at a higher dose of $100 \mu \mathrm{g} / \mathrm{ml}$ medium, and the greatest number of the leukemic cells was encountered after D-19575 application, at the same dose. A reduced

Table 2

The modal peaks of the volume distribution curves of ML-1 cells exposed to the action of D-17272, D-18864, and D-19575

\begin{tabular}{|c|c|c|c|c|c|}
\hline \multicolumn{3}{|c|}{ Group characteristic } & \multicolumn{3}{|c|}{ Modal peak (fL) } \\
\hline No. & agent given & agent dose & $24 \mathrm{~h}$ & $48 \mathrm{~h}$ & $72 \mathrm{~h}$ \\
\hline I & D-18864 & $10 \mu \mathrm{g} / \mathrm{ml}$ & 3181 & 3628 & 3222 \\
\hline II & D-17272 & $10 \mu \mathrm{g} / \mathrm{ml}$ & 2735 & 2290 & 1925 \\
\hline III & D-17272 & $100 \mu \mathrm{g} / \mathrm{ml}$ & 3506 & 7437 & 871 \\
\hline IV & D-19575 & $100 \mu \mathrm{g} / \mathrm{ml}$ & 1965 & 2168 & 1804 \\
\hline $\mathrm{V}$ & \multicolumn{2}{|c|}{ control } & 1682 & 1804 & 1601 \\
\hline
\end{tabular}


Table 3

The optical density of formazan solution determined after ML-1 cell exposure to the oxazaphosphorine agents

\begin{tabular}{|c|c|c|c|c|c|}
\hline \multirow{2}{*}{\multicolumn{3}{|c|}{ Group characteristic }} & \multicolumn{3}{|c|}{ Optical density of formazan solution $\left(\times 10^{-1}\right)$} \\
\hline & & & \multirow{2}{*}{$\begin{array}{c}24 \mathrm{~h} \\
\text { mean } \pm \mathrm{SD} \\
\end{array}$} & \multirow{2}{*}{$\begin{array}{c}48 \mathrm{~h} \\
\text { mean } \pm \mathrm{SD} \\
\end{array}$} & \multirow{2}{*}{$\begin{array}{c}72 \mathrm{~h} \\
\text { mean } \pm \mathrm{SD}\end{array}$} \\
\hline No. & agent given & agent dose & & & \\
\hline I & D-18864 & $10 \mu \mathrm{g} / \mathrm{ml}$ & $\begin{array}{c}2,4,5,48 \mathrm{~h}, 72 \mathrm{~h} \\
2.13 \pm 0.08\end{array}$ & $\begin{array}{c}2,3,4,5,24 \mathrm{~h} \\
3.16 \pm 0.07\end{array}$ & $\begin{array}{l}2,3,4,5,24 \mathrm{~h} \\
3.09 \pm 0.09\end{array}$ \\
\hline II & D-17272 & $10 \mu \mathrm{g} / \mathrm{ml}$ & $\begin{array}{c}1,3,5,48 \mathrm{~h}, 72 \mathrm{~h} \\
2.26 \pm 0.13\end{array}$ & $\begin{array}{c}1,3,5,24 \mathrm{~h}, 72 \mathrm{~h} \\
4.24 \pm 0.14 \\
\end{array}$ & $\begin{array}{c}1,3,4,5,24 \mathrm{~h}, 48 \mathrm{~h} \\
4.92 \pm 0.25\end{array}$ \\
\hline III & D-17272 & $100 \mu \mathrm{g} / \mathrm{ml}$ & $\begin{array}{c}2,4,5,48 \mathrm{~h}, 72 \mathrm{~h} \\
2.13 \pm 0.05\end{array}$ & $\begin{array}{c}1,2,4,5,24 \mathrm{~h} \\
2.92 \pm 0.06 \\
\end{array}$ & $\begin{array}{c}1,2,4,5,24 \mathrm{~h} \\
2.86 \pm 0.10 \\
\end{array}$ \\
\hline IV & D-19575 & $100 \mu \mathrm{g} / \mathrm{ml}$ & $\begin{array}{c}1,3,5,48 \mathrm{~h}, 72 \mathrm{~h} \\
2.45 \pm 0.14 \\
\end{array}$ & $\begin{array}{l}1,3,24 \mathrm{~h}, 72 \mathrm{~h} \\
4.27 \pm 0.15 \\
\end{array}$ & $\begin{array}{c}1,2,3,5,24 \mathrm{~h}, 48 \mathrm{~h} \\
5.13 \pm 0.12 \\
\end{array}$ \\
\hline V & \multicolumn{2}{|c|}{ control } & $\begin{array}{c}1,2,3,4,48 \mathrm{~h}, 72 \mathrm{~h} \\
2.57 \pm 0.07\end{array}$ & $\begin{array}{c}1,2,3,24 \mathrm{~h}, 72 \mathrm{~h} \\
4.33 \pm 0.17\end{array}$ & $\begin{array}{c}1,2,3,4,24 \mathrm{~h}, 48 \mathrm{~h} \\
5.49 \pm 0.09 \\
\end{array}$ \\
\hline
\end{tabular}

For explanation of signs, see Table 1.

Table 4

The count of ML-1 cells after their exposure to the oxazaphosphorine agents

\begin{tabular}{|c|c|c|c|c|c|}
\hline \multirow{2}{*}{\multicolumn{3}{|c|}{ Group characteristic }} & \multicolumn{3}{|c|}{ Cell count $\left(\mathrm{x} 10^{3}\right)$} \\
\hline & & & \multirow{2}{*}{$\begin{array}{c}24 \mathrm{~h} \\
\text { mean } \pm \mathrm{SD}\end{array}$} & \multirow{2}{*}{$\begin{array}{c}48 \mathrm{~h} \\
\text { mean } \pm \mathrm{SD}\end{array}$} & \multirow{2}{*}{$\begin{array}{c}72 \mathrm{~h} \\
\text { mean } \pm \mathrm{SD}\end{array}$} \\
\hline No. & agent given & agent dose & & & \\
\hline I & D-18864 & $10 \mu \mathrm{g} / \mathrm{ml}$ & $\begin{array}{l}2,4,5,48 \mathrm{~h}, 72 \mathrm{~h} \\
169.99 \pm 5.06\end{array}$ & $\begin{array}{l}2,3,4,5,24 \mathrm{~h}, 72 \mathrm{~h} \\
221.18 \pm 5.75\end{array}$ & $\begin{array}{l}2,3,4,5,24 \mathrm{~h}, 48 \mathrm{~h} \\
300.76 \pm 8.18\end{array}$ \\
\hline II & D-17272 & $10 \mu \mathrm{g} / \mathrm{ml}$ & $\begin{array}{l}1,3,4,5,48 \mathrm{~h}, 72 \mathrm{~h} \\
225.88 \pm 6.40\end{array}$ & $\begin{array}{c}1,3,4,5,24 \mathrm{~h}, 72 \mathrm{~h} \\
632.50 \pm 12.97\end{array}$ & $\begin{array}{c}1,3,4,5,24 \mathrm{~h}, 48 \mathrm{~h} \\
1049.91 \pm 14.08\end{array}$ \\
\hline III & D-17272 & $100 \mu \mathrm{g} / \mathrm{ml}$ & $\begin{array}{c}2,4,5,72 \mathrm{~h} \\
159.03 \pm 3.83\end{array}$ & $\begin{array}{c}1,2,4,5,72 \mathrm{~h} \\
155.59 \pm 5.86\end{array}$ & $\begin{array}{l}1,2,4,5,24 \mathrm{~h}, 48 \mathrm{~h} \\
134.62 \pm 4.57\end{array}$ \\
\hline IV & D-19575 & $100 \mu \mathrm{g} / \mathrm{ml}$ & $\begin{array}{c}1,2,3,5,48 \mathrm{~h}, 72 \mathrm{~h} \\
281.39 \pm 10.50\end{array}$ & $\begin{array}{c}1,2,3,5,24 \mathrm{~h}, 72 \mathrm{~h} \\
704.49 \pm 38.92\end{array}$ & $\begin{array}{c}1,2,3,5,24 \mathrm{~h}, 48 \mathrm{~h} \\
1150.73 \pm 79.70\end{array}$ \\
\hline $\mathrm{V}$ & \multicolumn{2}{|c|}{ control } & $\begin{array}{c}1,2,3,4,48 \mathrm{~h}, 72 \mathrm{~h} \\
374.63 \pm 14.07\end{array}$ & $\begin{array}{c}1,2,3,4,24 \mathrm{~h}, 72 \mathrm{~h} \\
818.78 \pm 63.04\end{array}$ & $\begin{array}{c}1,2,3,4,24 \mathrm{~h}, 48 \mathrm{~h} \\
1373.67 \pm 15.68\end{array}$ \\
\hline
\end{tabular}

For explanation of signs, see Table 1.

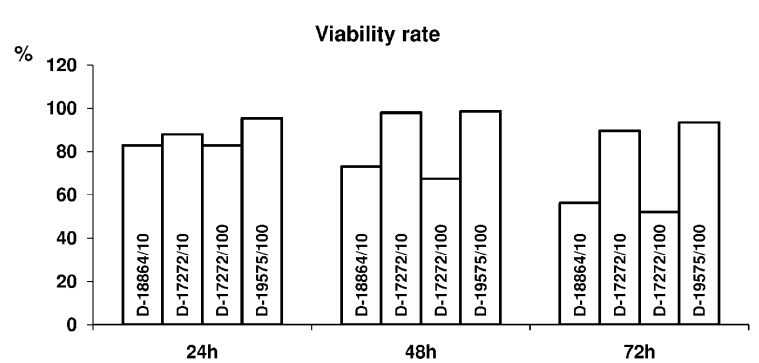

Fig. 2. Effects of the oxazaphosphorines on the viability rate of ML-1 cells. The extent of MTT conversion to formazan in ML-1 cells expressed as a percentage value of the control. D-18864/10 - D-18864 applied at a dose of 10 $\mu \mathrm{g} / \mathrm{ml}$ medium; D-17272/10 - D-17272 applied at a dose of $10 \mu \mathrm{g} / \mathrm{ml}$ medium; D-17272/100 - D-17272 applied at a dose of $100 \mu \mathrm{g} / \mathrm{ml}$ medium; D-19575/100 - D-19575 applied at a dose of $100 \mu \mathrm{g} / \mathrm{ml}$ medium. count of ML-1 cells exposed to D-17272 at two doses, $10 \mu \mathrm{g} / \mathrm{ml}$ and $100 \mu \mathrm{g} / \mathrm{ml}$ medium, appeared to be dose-dependent. The cell number was observed to be greater in ML-1 cells treated with $\mathrm{D}-17272$, at a dose of $10 \mu \mathrm{g} / \mathrm{ml}$ medium, than in those exposed to D-18864 at the same dose.

\section{Discussion}

The results of the present study have shown the human acute myeloblastic leukemia ML-1 cell response to the action of three new generation oxazaphosphorines D-17272, D-18864, and D-19575. Temporary alterations in the size, viability and count of ML-1 cells, observed 24h, 48h and $72 \mathrm{~h}$ 
after their exposure to the oxazaphosphorines agents, were dependent on the agent tested, its dose, and the time intervals after its application. Among the oxazaphosphorine agents, D-18864 appeared to be the most cytotoxic, and D-19575 was characterized by the lowest cytotoxicity. The variable leukemic cell responses to the action of the oxazaphosphorines, were found.

The cytotoxic effects of the oxazaphosphorines, D-17272, D-18864, and D-19575, surely resulted from their various action on human leukemic ML-1 cells. However, the precise mechanisms responsible for cytotoxicity of these three oxazaphosphorine agents on pathological hematopoietic cells have not yet been completely elucidated. It is accepted that phosphoramide mustard and acrolein are the major reactive alkylating agents of D-17272 and D-18864. D-19575 contains the direct alkylating moiety, isophosphoramide mustard. The reactive alkylating compounds are involved in the toxicologic reactions because they can bind to a variety of cellular molecules disturbing the normal processes occurring in the cell. Moreover, the cytotoxicity of these oxazaphosphorines is dependent on their pharmacokinetic and pharmacodynamic properties (BODY and YULE 2000; ZHANG et al., 2005a, 2005b; LIANG et al. 2007; GIRAUD et al. 2010; MAZUR et al. 2011).

The changes in the metabolic activity and cell viability, the volume and count of leukemic ML-1 cells following D-17272, D-18864, and D-19575 application can result from various alterations occurring in these cells at the molecular, biochemical and morphological levels. In the previous publication it has been shown that damage caused by the oxazaphosphorine agents in the hematopoietic cells was manifested as DNA breakage, cell cycle disruption, cell proliferation inhibition, mitotic catastrophe and programmed cell death - induction (MAZUR 2002; MAZUR et al. 2009, 2010; OPYDO-CHANEK et al. 2010a, 2010b).

To summarize, the results of the present investigations indicated that three analyzed parameters, cell volume, viability, and cell count are important in determining and comparing cytotoxic effects observed in human leukemic cells after their exposure to the new generation oxazaphosphorines. In conclusion, the electronic sizing and counting method and MTT assay can be used to study the anticancer activity of newly synthesized and tested, potential chemotherapeutic agents.

\section{Acknowledgements}

The authors wish to thank Urszula KŁAPUT for her excellent technical assistance.

\section{References}

Blaney S. M., Balis F. M., Berg S., ARndt C. A. S., HEIDEMAN R., GEYER J. R., PACKER R., ADAMSON P. C., JAECKLE K., Klenke R., AIKIN A., Murphy R., MC CULLY C., POPLACK D. G. 2005. Inthrathecal mafosfamide: Preclinical pharmacology and phase I trial. J. Clin. Oncol. 23: $1555-1563$.

Body A. V., Yule S. M. 2000. Metabolism and pharmacokinetics of oxazaphosphorines. Clin. Pharmakokinet. 38: 291-304.

Engel J., Klenner T., Niemeyer U., Peter G., Pohl J., SCHÜßLER M., SCHUPKE A., VOSS A., WEISSLER M. 2000. Glufosfamide. Drug. Future 25: 791-794.

Giraud B., Hebert G., Deroussent A., Veal G. L., VASSAL G., PACI A. 2010. Oxazaphosphorines: new therapeutic strategies for an old class of drugs. Expert. Opin. Drug Metab. Toxicol. 6: 919-938.

Goldstein M., Roos W. P., KAINA B. 2008. Apoptotic death induced by the cyclophosphamide analogue mafosfamide in human lymphoblastoid cells: Contribution of DNA replication, transcription inhibition and Chk/p53 signaling. Toxicol. Appl. Pharmacol. 229: 20-32.

Liang J., Huang M., DuAn W., Yu X. O., Zhou S. 2007. Design of new oxazaphosphorine anticancer drugs. Curr. Pharm. Des. 13: 963-978.

MAZUR L. 2002. Indukowanie apoptozy i nekrozy komórek hematopoetycznych przez tiole, promieniowanie jonizujace i związki chemioterapeutyczne (Induction of apoptosis and necrosis of hematopoietic cells by thiols, ionizing radiation and chemotherapeutic agents). Kraków, Księgarnia Akademicka, 1-120. (In Polish).

MAZUR L., OPYDO-CHANEK M., STOJAK M. 2011. Glufosfamide as a new oxazaphosphorine anticancer agent. AntiCancer Drug. 22: 488-493.

MAZUR L., OpYDO-CHANEK M., STOJAK M., BARAN J., NIEMEYER U. 2010. Induction of DNA breakage in U937 cells by oxazaphosphorines. Folia biol. (Kraków) 58: 15-20.

MAZUR L., STOJAK M., Opydo-ChaneK M., NiemEyer U. 2009. Mitotic catastrophe induction in U937 cells by oxazaphosphorines. Acta Biol. Cracov. Ser. Zool. 51: 17-22.

Opydo-ChaneK M., MAZUR L., StojaK M., NiemEyer U. 2010a. Comparative effects of new generation oxazaphosphorines on cancer cell death. 6th Swiss Apoptosis Meeting, Bern, Switherland, 46.

Opydo-ChaneK M., StojaK M., MazUR L., Niemeyer U. 2010b. Changes in the size of U937 cells following exposure to new generation oxazaphosphorines. Acta Biol. Cracov. Ser. Zool. 52: 25-29.

Seker H., Bertram B., Burkle A., Kaina B., Pohl J., KOEPSELL H., WIESSLER M. 2000. Mechanistic aspects of the cytotoxic activity of glufosfamide, a new tumor therapeutic agent. Br. J. Cancer 82: 629-634.

STYCZYŃSKI J., WYSOCKI M., DEBBSKI R., BALWIERZ W., ROKICKA-MILEWSKA R., MATYSIAK M., BALCERSKA A., KOWALCZYK J., WACHOWIAK J., SOŃTA-JAKIMCZYK D., CHYBICKA A. 2002a. In vitro activity of oxazaphosphorines in childhood acute leukemia: Preliminary report. Acta Biochim. Pol. 49: 221-225.

STYCZYŃSKI J., WYSOCKI M., KUR YLAK A., JURASZEWSKA E., MALINOWSKA I., STANCZAK E., PŁOSZYŃSKA A., STEFANIAK J., MAZUR B., SZCZEPAŃJJKI T., RAS M. $2000 \mathrm{~b}$. In vitro activity of glufosfamide in childhood acute leukemia. Anticancer Res. 22: 247-250.

Zhang J., Tian Q., Chan S.Y., DuAN W., Zhou S. 2005a. Insight into oxazaphosphorine resistance and possible approaches to its circumvention. Drug Resist. Uptake 8: 271-297.

ZHANG J., Tian Q., CHAn S. Y., Li S. C., ZHOU S. 2005b. Metabolism and transport of oxazaphosphorines and the clinical implications. Drug Metab. Rev. 37: 611-703. 